\title{
SPOŁECZNE ZRÓŻNICOWANIE UMIEJĘTNOŚCI INFORMATYCZNYCH REDUKCJA CZY REPRODUKCJA NIERÓWNOŚCI SPOŁECZNYCH?
}

\section{WPROWADZENIE}

Współczesne media to nie tylko prasa, radio, czy telewizja, ale także nowe środki komunikowania, jak np. Internet. Powstaniu globalnej sieci towarzyszyło nieco naiwne przekonanie, że stwarza ona niespotykane dotąd szanse na poprawę sytuacji życiowej wykluczonych czy upośledzonych społecznie grup, zmniejszenie nierówności i emancypację mniejszości, ponieważ umożliwi dotarcie do informacji, wiedzy i kontaktów w prosty i tani sposób ${ }^{1}$. Praktyka życia społecznego szybko zweryfikowała ten pogląd i pokazała, że Internet jest nie tyle obszarem niwelowania różnic między ludźmi, ile raczej sferą reprodukowania już istniejących podziałów i dystansów odtwarzania się struktury społecznej, stanowi bowiem (w nawiązaniu do koncepcji Pierre’a Bourdieu) zarówno źródło znaczących zasobów (kapitałów), jak i miejsce ich konwersji, wymiany i akumulacji ${ }^{2}$. Kluczowe jest tu założenie, że korzystanie z komputera i sieci nie jest obojętne dla sytuacji społecznej ich użytkowników, lecz stanowi czynnik zarówno warunkowany, jak i warunkujacy społeczną stratyfikację ${ }^{3}$.

\section{OD CYFROWEGO PODZIALU DO CYFROWYCH NIERÓWNOŚCI}

Omawiana problematyka, zwana w literaturze „cyfrowym podziałem” ${ }^{4}$ (digital divide), ewoluowała od prostych dychotomicznych wizji dzielących społeczeństwo na „użytkowników” i „nieużytkowników” (posiadających dostęp

${ }^{1}$ D. Batorski, Internet a nierówności społeczne, „Studia Socjologiczne” 2005, nr 2, s. 108, oraz P. DiMaggio et al., Social Implications of the Internet, „Annual Review of Sociology” 27, 2001, s. 310 .

${ }^{2}$ P. Bourdieu, The Forms of Capital, w: A. H. Halsey et al. (red.), Education: Culture, Economy, Society, Oxford University Press, Oxford 1997, s. 46-58. T. Zarycki, Spoteczne konsekwencje rozwoju Internetu - rewolucja czy reprodukcja struktur spotecznych?, w: D. Batorski, M. Marody, A. Nowak (red.), Społeczna przestrzeń Internetu, Wyd. SWPS „Academica”, Warszawa 2006.

${ }^{3}$ E. Hargittai, The Digital Reproduction of Inequality, w: D. Grusky (red.), Social Stratification, CO: Westview Press, Boulder 2008, s. 936-937.

${ }^{4}$ M. Cebula, Internet a struktura społeczna - problem cyfrowego podziatu, w: A. Dytman-Stasieńko, J. Stasieńko (red.), Język @ multimedia 3. Dialog - konflikt, WN DSW, Wrocław 2012, s. $43-57$. 
i nieposiadających), w stronę ujęć wielowymiarowych - ukazujących istotne znaczenie nie tylko samego dostępu, lecz także motywacji, umiejętności i efektywności wykorzystania technologii (kwestia nierówności wśród samych internautów), stąd postulat zastapienia terminu „podział”, terminem „cyfrowe

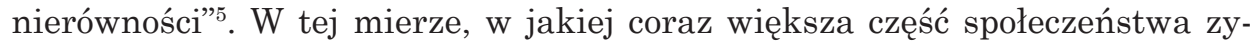
skuje akces do globalnej sieci, a zarazem sieć ta staje się stopniowo głównym i jedynym źródłem informacji i zasobów, rośnie znaczenie kompetencji w wykorzystaniu szans potencjalnie oferowanych wszystkim użytkownikom. Jednak, jak wskazują badania Nicole Zillien i Eszter Hargittai z 2004 r., sposób korzystania z Internetu (a co za tym idzie - potencjalne korzyści społeczne) zależy od uprzednio posiadanych kapitałów i kompetencji, a to z kolei sprawia, że to osoby już społecznie uprzywilejowane (lepiej wykształcone o wyższych zarobkach) w większej mierze angażują się w czynności zwiększające posiadane zasoby, przez co zwrotnie umacniaja swoja pozycję społeczną ${ }^{6}$. Inaczej mówiąc, Internet przynosi korzyści tym, którzy z racji wyższego kapitału wiedza, jak się nim posługiwać.

Co istotne, różnice klasowo-statusowe utrzymują się także w populacji ludzi młodych, co podważa popularny pogląd, że osoby dorastające w okresie rewolucji cyfrowej sa równie kompetentne w zakresie przyswojenia nowych technologii i stanowią pod tym względem homogeniczną grupę, nazywana zbiorczo „generacja sieci”, „cyfrowym pokoleniem” (Net generation, digital natives $)^{7}$. Otóż z badań Hargittai ${ }^{8}$ prowadzonych w jednorodnej grupie wiekowej studentów posiadających dostęp do sieci wynika, że zakres przejawianych umiejętności oraz wszechstronność wykorzystania Internetu były znacząco skorelowane ze zmiennymi strukturalnymi w ten sposób, że osoby o wyższym statusie społeczno-ekonomicznym (tj. posiadajace lepiej wykształconych rodziców), mężczyźni, biali i osoby pochodzenia azjatyckiego wykazywały większa biegłość w użytkowaniu sieci, i to nawet przy kontroli takich zmiennych, jak: doświadczenie (liczba lat kontaktu z Internetem i częstość korzystania) czy autonomia użycia (np. posiadanie laptopa). Okazuje się więc, że sam dostęp do technologii nie wyczerpuje problematyki nierówności, jako że sama technologia silnie zakorzeniona jest $\mathrm{w}$ życiu społecznym.

Kontynuując ten wątek, warto odwołać się do wpływowej koncepcji struktury społecznej Pierre’a Bourdieu9. Dowodził on, że podobne warunki życia (warunki klasowe) wyznaczone dystrybucją różnych form kapitału (ekonomicznego, kulturowego, społecznego i symbolicznego) znajdują swoje socjali-

${ }^{5}$ P. DiMaggio et al., Digital Inequality: From Unequal Access to Differentiated Use, w: K. Neckerman (red.), Social Inequality, Russell Sage Foundation, New York 2004, s. 355-400. Por. też J. van Dijk, K. Hacker, The Digital Divide as a Complex and Dynamic Phenomenon, „The Information Society” 19, 2003.

${ }^{6}$ N. Zillien, E. Hargittai, Digital Distinction: Status-Specific Types of Internet Usage, „Social Science Quarterly" 90, 2009, s. 274-291.

${ }^{7}$ M. Prensky, Digital Natives, Digital Immigrants, „On the Horizon” 9, 2001, s. 1-6; idem, Do They Really Think Differently, „On the Horizon” 9, 2001, s. 7-15.

${ }^{8}$ E. Hargittai, Digital Na(t)ives? Variation in Internet Skills and Uses among Members of the "Net Generation”, „Sociological Inquiry” 80, 2010, s. 93-113.

${ }^{9}$ P. Bourdieu, Dystynkcja. Społeczna krytyka władzy sqdzenia, WN Scholar, Warszawa 2005. 
zacyjne przedłużenie w klasowych habitusach, tj. systemach schematów percepcji, myślenia, oceniania i działania, które na zasadzie systematycznych transpozycji generuja spójne praktyki i upodobania w różnych wycinkach życia (produkują spójne style życia). Obserwowane odmienności w sposobach korzystania z Internetu mogą być interpretowane nie tylko jako wyraz transmisji środowiskowych wzorów zachowań, wsparcia społecznego, kompetencji formalnych czy możliwości ekonomicznych, lecz także jako wyraz odmiennych dyspozycji (głęboko ukrytych nastawień, sposobów patrzenia na świat, praktycznych filozofii czy postaw) klasowego habitusu, który niejednakowo wyposaża jednostki w zdolności percypowania i rozpoznawania szans, w tym tych oferowanych przez nowe technologie.

Dla przykładu w badaniach australijskich prowadzonych metodami jakościowymi (wywiady pogłębione i dzienniczki czasu) zaobserwowano, że rodzaj „cyfrowych gustów” piętnastoletnich uczniów silnie korespondował z ich pochodzeniem społecznym (wyznaczonym przez zawód i wykształcenie rodziców oraz miejsce zamieszkania) ${ }^{10}$. Mimo że badani posiadali podobny dostęp do technologii w domu i szkole, a także zbliżony poziom wiedzy, to rodzaj podejmowanych przez nich praktyk i przejawianych zainteresowań był wyraźnie naznaczony typem doświadczeń socjalizacyjnych wyniesionych $\mathrm{z}$ domu. Te ostatnie wynikały np. z bezpośrednich postaw i zachowań rodziców wobec nowych technologii (np. to, do czego oni sami wykorzystywali komputer, lub jakie wymagania i oczekiwania mieli wobec dzieci), jak i ogólniejszych nastawień dorosłych wobec edukacji, awansu społecznego czy rozwijania zainteresowań. Znamienny był przypadek imigrantów, którzy w wykształceniu dzieci widzieli szansę na przedłużenie swojej wznoszącej trajektorii życiowej ${ }^{11}$. W rezultacie, w zależności od ukształtowanych dyspozycji i systemu zachęt, część uczniów wykazywała silną orientację na akumulację kapitału szkolnego (np. wykorzystując Internet do nauki i samorozwoju), podczas gdy pozostali (o innym bagażu wzorców) orientowali się raczej na rozrywkowe aspekty nowych mediów, w tym na wartości opozycyjne wobec szkoły (np. słuchanie muzyki czy wysyłanie wiadomości tekstowych podczas zajęć). Rodzaj habitusu klasowego ('́ciślej rodzinnego) warunkował więc absorpcję kapitału kulturowego oferowanego przez szkołę, co potencjalnie przekładało się na późniejsze szanse życiowe (szanse zajmowania pozycji społecznych).

Społeczny charakter mediów elektronicznych ujawniają także badania nad tzw. umiejętnościami internetowymi, stanowiącymi bardziej zniuansowane podejście do cyfrowych nierówności ${ }^{12}$. Dociekając relatywnego wpływu takich zmiennych, jak: płeć, wiek, poziom wykształcenia, doświadczenie w korzystaniu i intensywność użycia Internetu na poziom umiejętności, holenderscy badacze skupili się na dwóch ich aspektach: tj. umiejętnościach

10 S. North, I. Snyder, S. Bulfin, Digital Tastes. Social Class and Young People's Technology Use, „Information, Communication \& Society” 11, 2008, s. 895-911.

${ }_{11}$ Por. P. Bourdieu, Dystynkcja..., s. 429-435.

12 A. J. A. M. van Deursen, J. A. G. M. van Dijk, O. Peters, Rethinking Internet Skills: The Contribution of Gender, Age, Education, Internet Experience, and Hours Online to Mediumand Content-Related Internet Skills, „Poetics” 39, 2011, s. 125-144. 
związanych z medium (dotyczących spraw technicznych, obsługi, nawigacji i orientacji w środowisku internetowym) oraz (istotnych ze społecznego punktu widzenia) umiejętnościach związanych z zawartością (obejmujących poszukiwanie informacji i wykorzystania Internetu dla realizacji praktycznych celów, np. zaplanowania podróży). Prowadząc bezpośredni pomiar umiejętności (w formie zadań testowych) na zróżnicowanej pod względem cech społeczno-demograficznych populacji, ustalili, że wiek korelował negatywnie z umiejętnościami związanymi z medium (biegłością techniczno-operacyjna). Co istotne, osoby starsze lepiej radziły sobie z zawartościa, pod warunkiem jednak przekroczenia bariery technicznego opanowania. Formalne wykształcenie powiększało zakres umiejętności obu typów, podczas gdy umiejętności związane z zawartością nie zależały od długości doświadczenia z Internetem ani od intensywności w jego korzystaniu. Można powiedzieć, że o ile umiejętności techniczne to w pewnej mierze kwestia wprawy, ćwiczeń metodą prób i błędów, o tyle bardziej strategiczne zdolności praktycznego wykorzystania sieci (poszukiwania, selekcji, przetwarzania i oceny informacji) to już kwestia uprzedniego wyposażenia w stosowny kapitał kulturowy (tutaj ujmowany przez wykształcenie) ${ }^{13}$.

W rezultacie dostęp do Internetu i sposób jego wykorzystania korespondują z istniejącymi podziałami klasowymi ${ }^{14}$. Co więcej, cyfrowe kompetencje staja się w warunkach społeczeństwa informacyjnego czy sieciowego nowym typem kapitału kulturowego, źródłem nowych społecznych segmentacji, np. wskazywanego przez Manuela Castellsa podziału na „kosmopolityczna i mobilną elitę" zamieszkująca globalną przestrzeń przepływów i „lokalne masy”, pozbawione rozeznania i władzy w społeczeństwach sieciowych ${ }^{15}$.

\section{STRUKTURA SPOLECZNA A KORZYSTANIE Z INTERNETU. KLASOWE PODZIAŁY MIESZKAŃCÓW WROCŁAWIA?}

Empiryczną ilustrację problematyki społecznego zróżnicowania praktyk internetowych stanowią wyniki projektu badawczego „Symboliczny wymiar konsumpcji we współczesnej kulturze w świetle badań mieszkańców Wrocławia" ${ }^{16}$, zrealizowanego na niereprezentatywnej próbie dorosłych mieszkańców Wrocławia w czerwcu i lipcu 2011 r. Celem projektu było uchwycenie zależności między pozycją społeczną a orientacjami, praktykami i upodobaniami kulturowo konsumpcyjnymi z różnych dziedzin życia, w tym tych dotyczących konsumpcji i korzystania z mediów. W przypadku Internetu przedmiotem dociekań było nie tylko społeczne zróżnicowanie w samym dostępie do Internetu, ale przede wszystkim to, jak położenie społeczne określa sposób ko-

13 Ibidem, s. 137.

14 A. Prieur, L. Rosenlund, J. Skjott-Larsen, Cultural Capital Today. A Case Study from Denmark, „Poetics” 36, 2008, s. 45-71, oraz A. Prieur, M. Savage, Updating Cultural Capital Theory: A Discussion Based on Studies in Denmark and in Britain, „Poetics” 39, 2011, s. 566-580.

15 M. Castells, Społeczeństwo sieci, WN PWN, Warszawa 2007.

16 Projekt został sfinansowany ze środków Narodowego Centrum Nauki: umowa nr 4954/B/ H03/2011/40 do wniosku N N116 495440. 
rzystania z globalnej sieci. Ponieważ założono klasowy charakter świata społecznego, respondentów dobierano według aktualnie wykonywanego zawodu, zgodnie z ugruntowanymi socjologicznie argumentami, że zawód stanowi najbardziej adekwatny wskaźnik społecznego usytuowania ${ }^{17}$. Zdefiniowano trzy ogólne kategorie „klasowe” badanych: kategorię A stanowiły kadry kierownicze i menedżerowie, przedsiębiorcy wraz z właścicielami warsztatów pracy i samozatrudniającymi się (jeśli byli jednocześnie specjalistami), inteligencja techniczna i nietechniczna, kategorię B: technicy, wyspecjalizowani pracownicy administracyjno-biurowi oraz pozostali pracownicy biurowi (tzw. zawody umysłowe), a także część pracowników handlu i usług (tj. tych mających kwalifikacje). Trzecią kategorię - C - tworzyli: szeregowi pracownicy zatrudnienie w handlu i usługach, pracownicy fizyczni oraz niewykwalifikowani pracownicy usług. Jako materiał badawczy posłużyły wypowiedzi zgromadzone podczas 362 wywiadów kwestionariuszowych (ilościowych) ${ }^{18}$ oraz cytaty zaczerpnięte $\mathrm{z}$ wywiadów swobodnych $(\mathrm{n}=18)$. Choć zastosowany dobór próby (celowy) wykluczył możliwość wnioskowania statystycznego, to jednak dawał szansę systematycznych porównań międzyklasowych i wykrywania tą droga socjologicznych regularności, znajdujących poparcie zarówno w teorii, jak i w wynikach innych badań.

Po pierwsze można się przekonać, że samo korzystanie z sieci uwarunkowane jest społeczną przynależnością badanych (wykres 1) i różnice te są istotne statystycznie $^{19}$. Podczas gdy $89 \%$ przedstawicieli grupy A (tj. wyższych kadr,

\section{Wykres 1}

Kategorie „klasowe” a częstotliwość korzystania z Internetu (\% osób z danej kategorii)

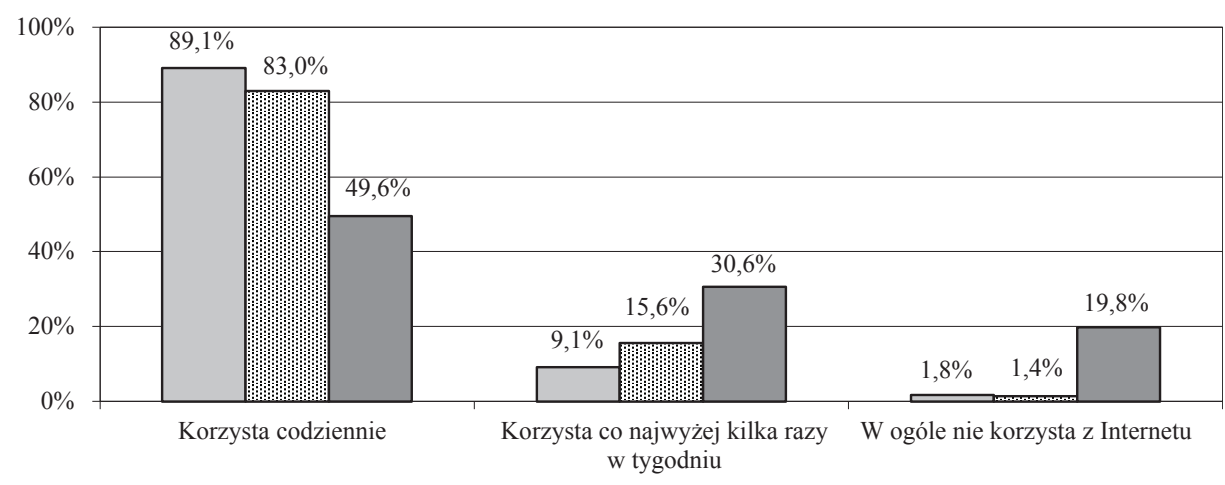

口Kategoria A BKategoria B $\square$ Kategoria C

Źródło: opracowanie własne.

${ }^{17}$ H. Domański, Z. Sawiński, K. M. Słomczyński, Nowa klasyfikacja i skale zawodów. Socjologiczne wskaźniki pozycji społecznej w Polsce, IFiS PAN, Warszawa 2007.

18 Przebadano odpowiednio: 110 osób z kategorii A, 141 z kategorii B i 111 z kategorii C.

${ }^{19} \mathrm{X}^{2}(4, \mathrm{~N}=362)=64,3 ; \mathrm{p}<0,001$. Współczynnik V Cramera $=0,298 ; \mathrm{p}<0,001$. 
menedżerów, specjalistów i przedsiębiorców) korzystało codziennie z Internetu, wśród osób tworzących segment $\mathrm{C}$ (pracowników fizycznych, handlu i usług) codziennych użytkowników było tylko 49,6\%, a aż 19,8\% osób w ogóle nie miało styczności z tym medium. To także w grupie C najwięcej było osób łączących się z Internetem co najwyżej kilka razy w tygodniu (30,6\%). Pozycję pośrednią zajmowali reprezentanci kategorii B, spośród których $83 \%$ codziennie zasiadało przed komputerem, a 15,6\% - kilka razy w tygodniu lub rzadziej.

Rozkład pozostałych zmiennych społecznych i demograficznych potwierdza znane $\mathrm{z}$ innych badań prawidłowości w zakresie społecznych dysproporcji $\mathrm{w}$ wykorzystaniu technologii informacyjno-komunikacyjnych ${ }^{20}$. Z Internetu częściej korzystają mężczyźni niż kobiety (3\% niekorzystających wobec $9,7 \%)^{21}$, osoby z wykształceniem wyższym $(88,5 \%$ korzystających codziennie wobec $9,4 \%$ wśród legitymujących się wykształceniem niższym niż średnie), lepiej zarabiające $(94,1 \%$ regularnych użytkowników w grupie dochodowej „powyżej 3000 zł” wobec 49,1\% w grupie „poniżej 1000 zł” dochodu per capita), młodsze (90,9\% osób w wieku 18-25 lat codziennie przeglądających Internet w porównaniu z 27,9\% w grupie najstarszej: powyżej 55 lat), zajmujące „wyższe" pozycje zawodowe (0\% niekorzystajacych wśród kierowników wobec $23,5 \%$ wśród zatrudnionych w handlu i usługach), zamieszkałe w „lepszych” dzielnicach (np. mieszkańcy nowych osiedli wybudowanych po 2000 r. w $91 \%$ codziennie korzystających z sieci wobec 57,4\% mieszkańców starych kamienic) ${ }^{22}$. Niektóre z tych cech sa ze sobą skorelowane (nakładają się na siebie), jak np. wykształcenie i dochód (rho $=0,553 ; \mathrm{p}<0,001$ ), wykształcenie i wiek $(\mathrm{r}=-0,358 ; \mathrm{p}<0,001)$ czy dochód i miejsce zamieszkania (V-Cramera $=0,171$; p < 0,01), przez co za niższą intensywność użytkowania odpowiada zapewne łączne współwystępowanie niższego kapitału kulturowego, ekonomicznego czy wyższego wieku. Na przykład w modelu regresji logistycznej, w którym zmienna wyjaśniana miała charakter kontrastowy (korzystający codziennie z sieci vs niekorzystający w ogóle lub rzadziej niż raz w miesiącu; $\mathrm{N}=260$ ), wzrost wieku o jednostkę analizy powodował zmniejszenie prawdopodobieństwa wystapienia zdarzenia (tutaj korzystania z Internetu codziennie) o 66,6\% ( $p<0,001)$, z kolei wzrost dochodu zwiększał szanse o 75,6\% ( $<<0,05)$, a wykształcenia - aż o 263\% (p < 0,001). Mając do dyspozycji tylko wartości zmiennych niezależnych, można było poprawnie zaklasyfikować $96,5 \%$ respondentów, tj. przewidzieć, czy będą należeli do grupy korzystających z sieci codziennie, czy też do grupy niekorzystających w ogóle (lub rzadziej niż raz w miesiącu).

Już zaledwie to zestawienie pokazuje, jak mocno w realiach struktury społecznej i podziałów innego typu osadzona jest praktyka korzystania z „nowych mediów", co nadaje jej głęboko społeczny i kulturowy charakter. Co więcej, korzystanie z sieci koreluje pozytywnie z kapitałem społecznym. Na przykład

20 D. Batorski, Korzystanie z technologii informacyjno-komunikacyjnych, w: J. Czapiński, T. Panek (red.), Diagnoza społeczna 2011. Warunki i jakość życia Polaków, „Contemporary Economics" 5, 2011, s. 307-311.

21 Różnica istotna statystycznie przy $\mathrm{p}<0,05$.

${ }^{22}$ Różnice istotne statystycznie przy p <0,001 a w przypadku miejsca zamieszkania p < 0,01. 
osoby, które codziennie surfują po Internecie posiadają więcej przyjaciół spoza rodziny $(M=4,98)$ niż korzystające kilka razy w tygodniu $(M=3,23)$, czy w ogóle niekorzystajace $(\mathrm{M}=2,92)^{23}$. Także częstotliwość spotkań z rodzina, a zwłaszcza z przyjaciółmi spoza rodziny wiąała się z użytkowaniem tego medium (odpowiednio: eta $=0,162 \mathrm{i}$ eta $=0,450)^{24}$. Co istotne, zaobserwowana zależność była silniejsza w przypadku relacji pozarodzinnych i pozadomowych niż rodzinnych. Mówiąc inaczej, bycie Internautą idzie raczej w parze z posiadaniem większej liczby przyjaciół niebędących krewnymi niż utrzymywaniem bliskich relacji z rodziną. Choć stwierdzona zależność znajduje potwierdzenie w wynikach innych badań ${ }^{25}$, to trudno rozstrzygnąć, czy ma ona charakter przyczynowo-skutkowy, czy też jedynie korelacyjny (zapośredniczony wpływem innych zmiennych, takich jak wiek, wykształcenie, dochód itp.). W pierwszym przypadku można dowodzić, że Internet bądź ułatwia utrzymywanie lub/i nawiązywanie relacji (zarówno bezpośrednio, jak i wyposażając jednostkę w zasoby interakcyjne), bądź też same relacje stanowią bodziec do intensywniejszego wykorzystania technologii (znowu w postaci zarówno bezpośredniego „wsparcia”, jak i pośredniego „naśladownictwa” czy inspiracji, źródła wiedzy czy motywacji). Niewątpliwie jednak, wbrew obiegowym opiniom, Internet nie zagraża społecznej spójności ani nie powoduje izolacji czy atomizacji życia społecznego.

Osobnym zagadnieniem jest to, czy „nowe media” stanowią konkurencję dla „starszych” form komunikowania, takich jak telewizja czy prasa. Z innych analiz prowadzonych w ramach omawianego projektu wynikało, że istnieje tendencja do zastępowania telewizji „tradycyjnej” kontaktem z mediami interaktywnymi. Najwięcej czasu na oglądanie telewizji poświęcają osoby, które nie korzystają z Internetu, najmniej zaś korzystające codziennie (współczynnik korelacji eta $=0,342)^{26}$. Jednakże użytkowanie sieci nie powoduje zmniejszenia aktywności czytelniczych w zakresie prasy. Wręcz przeciwnie, częściej po prasę (zwłaszcza czasopisma) sięgają użytkownicy niż nieużytkownicy $(\text { eta }=0,255)^{27}$.

O tym, że Internet nie musi zagrażać tradycyjnym formom kultury, świadczy bardzo silna pozytywna zależność między korzystaniem z Internetu a aktywnościa sportową (eta $=0,392)^{28}$, czytelnictwem książek (eta $\left.=0,426\right)$, chodzeniem do kina (eta $=0,594)$, teatru, opery lub filharmonii (eta $=0,407)$, do muzeum, na wystawy lub do galerii (eta $=0,462)$, na koncerty muzyki rozrywkowej (eta $=0,395) !^{29}$ Nie musi to jednak oznaczać, że sam dostęp do

${ }^{23}$ Różnice istotne statystycznie przy p $<0,001$.

${ }^{24}$ Różnice istotne statystycznie przy odpowiednio $\mathrm{p}<0,05$ i $\mathrm{p}<0,001$.

25 D. Batorski, Korzystanie..., s. 318.

${ }^{26}$ Różnice istotne statystycznie przy p $<0,001$.

27 Różnice istotne statystycznie przy $\mathrm{p}<0,001$.

28 Naturalnie aktywność sportowa zależała dodatnio od wykształcenia ( $r h o=0,408$; $\mathrm{p}<0,001)$, dochodu (rho =0,295; p < 0,001) i aktywności towarzyskiej (spotkania z przyjaciółmi; rho $=0,361 ; p<0,001)$ oraz ujemnie od wieku (rho $=-0,344 ; \mathrm{p}<0,001)$. Sa to więc te same zmienne, które różnicują korzystanie z Internetu (związek aktywności fizycznej z korzystaniem z Internetu może mieć charakter pozorny).

${ }^{29}$ Aktywność sportową mierzono na skali 4-punktowej, pozostałe zmienne na skalach 5-punktowych. Wszystkie różnice są istotne statystycznie przy p $<0,001$. 
sieci zwiększa automatycznie poziom uczestnictwa w kulturze, ale raczej (jak wskazują też inni badacze ${ }^{30}$ ), poziom partycypacji kulturalnej i korzystanie z Internetu związane sa ze zmiennymi społeczno-demograficznymi (np. kapitałem kulturowym ich użytkowników). Faktycznie, z analizy regresji wielokrotnej zmiennej „uczestnictwo w kulturze" ${ }^{31}$ wynikało, że jest ona wyjaśniana przez podobne zmienne, jak te dotyczacce korzystania z sieci: wiek $(B=-0,143 ; p<0,01)$, wykształcenie $(B=0,232 ; p<0,001)$, dochód na jedna osobę w gospodarstwie domowym $(B=0,133$; $p<0,01)$, kapitał społeczny, tj. częstotliwość spotkań towarzyskich z przyjaciółmi i znajomymi spoza rodziny $(B=0,218 ; p<0,001)$ oraz częstotliwość spotkań poza domem $(B=0,281$; $\mathrm{p}<0,001)^{32}$. Co jednak ważne, włączenie do modelu zmiennej „korzystanie z Internetu codziennie" (zmienna dychotomiczna), spowodowało niewielka choć istotna statystycznie zmianę proporcji wyjaśnionej wariancji: $\mathrm{F}(1,306)$ $=7,97 ; \mathrm{p}<0,01$ (nowe skorygowane $\mathrm{R}^{2}=0,503$ ). Może to sugerować, że Internet niejako dodatkowo zwiększa poziom kulturowej partycypacji (szczególnie przy codziennym korzystaniu), niezależnie od czynników związanych ze struktura społeczna. Świadczyłoby to, że omawiana technologia informacyjno-komunikacyjna „polepsza” sytuację społeczna jednostek (tutaj ujmowana przez odwołanie do „kultury”).

Kwestią do rozstrzygnięcia pozostaje jeszcze, czy nierówności dotykaja także samych Internautów, tj. czy osoby różniące się cechami stratyfikacyjnymi wykazują odmienne sposoby i kierunki wykorzystania oferty internetowej (np. oddaja się bardziej rozrywce bądź nauce itp.). W tabeli 1 zestawiono główne cele, dla których z Internetu korzystały osoby zajmujące odmienne pozycje „klasowe” ${ }^{33}$. Widzimy, że przedstawiciele kategorii A (ale także osoby z wyższym wykształceniem i o wyższym dochodzie) przejawiali w większym stopniu nastawienie na te korzyści, co do których można domniemywać, iż poprawiają ich pozycję społeczna. Na przykład $80,6 \%$ wykorzystywało Internet w pracy zawodowej, 56,5\% - dla zdobywania i poszerzania wiedzy ${ }^{34}$, a 54,6\% do przeglądania informacji bieżących. Natomiast wśród należących do kategorii C (i posiadających niższe wykształcenie) relatywnie największy jest odsetek tych, dla których Internet jest źródłem rozrywki i relaksu $(43,8 \%)$ czy sposobem na utrzymywanie lub nawiązywanie znajomości - 56,2\% (choć to ostatnie może być zarówno źródłem przewagi, jak i nie wiązać się z poprawą pozycji).

${ }^{30}$ M. Filiciak, J. Hofmokl, A. Tarkowski, Obiegi kultury. Społeczna cyrkulacja treści. Raport $z$ badań, Centrum Cyfrowe, Warszawa 2012.

${ }^{31}$ Zmienna syntetyczna utworzona metodą regresyjną z analizy głównych składowych 5 zmiennych: a) chodzenie do muzeum, na wystawy, do galerii itp., b) chodzenie na koncerty muzyki rozrywkowej, c) chodzenie do teatru, opery lub filharmonii, d) chodzenie do kina, e) chodzenie na imprezy masowe typu festyny, targi, festiwale.

${ }^{32}$ Model regresji był dobrze dopasowany do danych: $F(5,307)=61,311 ; p<0,001$. Skorygowane $R^{2}=0,491$.

${ }^{33}$ Badani wybierali maksymalnie 4 odpowiedzi z listy 10 celów. Z tego względu odpowiedzi nie sumuja się do $100 \%$.

${ }^{34}$ Różnice na granicy istotności statystycznej $(p<0,055)$. 


\section{Tabela 1}

Kategorie „klasowe” a cele wykorzystania Internetu (\% w kolumnach)

\begin{tabular}{|l|c|c|c|c|}
\hline \multirow{2}{*}{ Cele wykorzystania Internetu } & \multicolumn{2}{|c|}{ Kategoria „klasowa” } & \multirow{2}{*}{ Ogółem } \\
\cline { 2 - 4 } & $\begin{array}{c}\text { Kategoria } \\
\mathbf{A}\end{array}$ & $\begin{array}{c}\text { Kategoria } \\
\mathbf{B}\end{array}$ & $\begin{array}{c}\text { Kategoria } \\
\text { C }\end{array}$ & \\
\hline Praca zawodowa* & $\mathbf{8 0 , 6 \%}$ & $65,2 \%$ & $21,3 \%$ & $58,5 \%$ \\
\hline $\begin{array}{l}\text { Praktyczne aspekty życia, np. rezer- } \\
\text { wacja biletów, sprawdzanie rozkładów } \\
\text { jazdy, sprawdzanie prognozy pogody }\end{array}$ & $\mathbf{7 6 , 9 \%}$ & $\mathbf{7 6 , 8} \%$ & $67,4 \%$ & $74,3 \%$ \\
\hline $\begin{array}{l}\text { Zdobywanie i poszerzanie wiedzy, } \\
\text { nauka }\end{array}$ & $\mathbf{5 6 , 5 \%}$ & $50,0 \%$ & $39,3 \%$ & $49,3 \%$ \\
\hline Zakupy i aukcje & $\mathbf{3 8 , 0 \%}$ & $34,1 \%$ & $22,5 \%$ & $32,2 \%$ \\
\hline $\begin{array}{l}\text { Kontakty z ludźmi - i utrzymywanie, } \\
\text { nawiązywanie** }\end{array}$ & $38,0 \%$ & $48,6 \%$ & $\mathbf{5 6 , 2} \%$ & $47,2 \%$ \\
\hline Rozrywka, relaks** & $27,8 \%$ & $31,2 \%$ & $\mathbf{4 3 , 8 \%}$ & $33,4 \%$ \\
\hline $\begin{array}{l}\text { Ściaganie filmów, muzyki, darmowego } \\
\text { oprogramowania }\end{array}$ & $20,4 \%$ & $15,9 \%$ & $22,5 \%$ & $19,1 \%$ \\
\hline $\begin{array}{l}\text { Przeglądanie serwisów informacyjnych } \\
\text { oraz internetowych wersji gazet lub } \\
\text { czasopism }\end{array}$ & $\mathbf{5 4 , 6 \%}$ & $49,3 \%$ & $41,6 \%$ & $49,0 \%$ \\
\hline Telefonowanie (np. Skype) & $\mathbf{1 9 , 4 \%}$ & $14,5 \%$ & $13,5 \%$ & $15,8 \%$ \\
\hline Gry & $6,5 \%$ & $9,4 \%$ & $9,0 \%$ & $8,4 \%$ \\
\hline Liczebność & 108 & 138 & 89 & 335 \\
\hline
\end{tabular}

* Różnice istotne statystycznie przy p <0,001

** Różnice istotne statystycznie przy $\mathrm{p}<0,05$

Źródło: opracowanie własne.

Wśród „górnych” warstw zawodowych wyższy jest także odsetek Internautów - klientów sklepów wirtualnych i uczestników aukcji (38\% wobec $22,5 \%$ $\mathrm{w}$ grupie C) ${ }^{35}$, co może wynikać zarówno $\mathrm{z}$ większych kompetencji cyfrowych tej grupy, jak i mniejszych zasobów czasu wolnego. Wykorzystanie sieci w celach praktycznych łączyło przedstawicieli kategorii A i B (ok. 77\% osób w obu grupach wskazywało na ten cel) i jednocześnie odróżniało ich od pracowników z grupy C $(67,4 \%)$.

Na społeczny charakter „nowych mediów” wskazuje pozytywny związek między używaniem Internetu do utrzymywania i nawiązywania kontaktu z innymi ludźmi a stopniem towarzyskości (częstotliwością spotkań z przyjaciółmi, znajomymi spoza rodziny) w świecie „realnym” (eta $=0,205)^{36}$. Zwłaszcza dla młodszych badanych Internet stanowił ważne narzędzie socjalizacji

${ }^{35}$ Różnice na granicy istotności statystycznej $(\mathrm{p}<0,057)$.

${ }^{36}$ Różnice istotne statystycznie przy $\mathrm{p}<0,001$. 
ułatwiające podtrzymywanie więzi i partycypację społeczną: „[...] w takim wypadku Facebook jako źródło wiedzy: co u moich znajomych jest, się dzieje ciekawego. No bo ze względu, że nie mam z nimi stałego kontaktu (możemy sobie pozwolić na jeden dzień spędzenia razem i spotkania się i tak dalej), no to Facebook stanowczo jest taką platforma, która mi pozwala na podgladanie co się dzieje u moim znajomych [...]" (młody mężczyzna, sprzedawca w sklepie z odzieża). W grupie wiekowej 18-25 lat aż $75 \%$ osób korzystało z Internetu ze względu na kontakty społeczne, natomiast w kategorii osób powyżej 55 roku życia ten odsetek wyniósł $27,3 \%{ }^{37}$. Trudno jednak powiedzieć, czy samo korzystanie z Internetu powoduje przyrost kapitału społecznego (pewne dane, choć niejednoznacznie na to wskazują ${ }^{38}$ ), czy też raczej już posiadany kapitał znajduje swój „wirtualny” korelat w postaci np. udzielania się na portalach społecznościowych.

Rozwinięciem rozważań na temat dyferencjacji sposobów i kierunków wykorzystania Internetu są dane przedstawione na schemacie 1.

\section{Schemat 1}

Dwa wymiary wykorzystania Internetu a zmienne społeczno-ekonomiczne

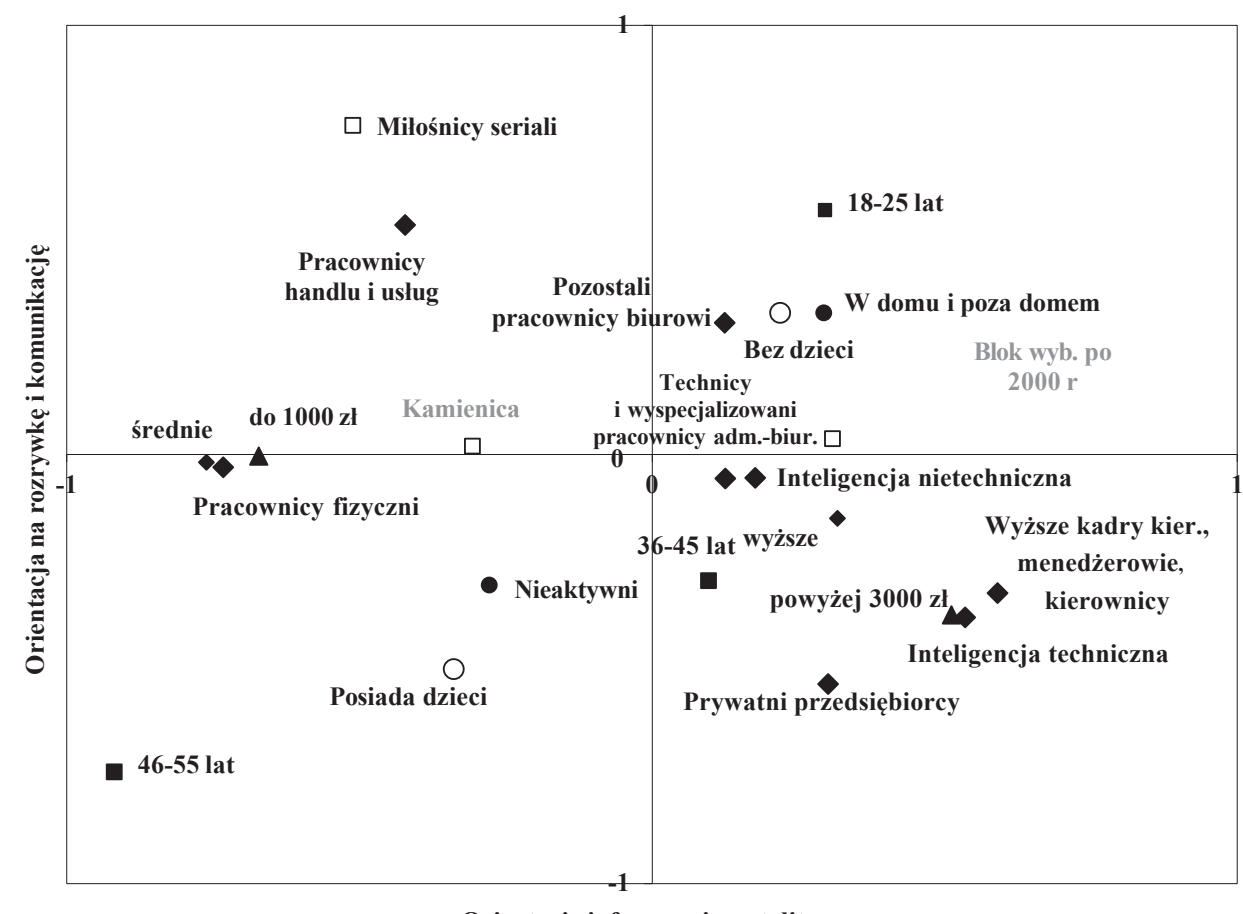

Orientacja informacyjno-utylitarna

Źródło: opracowanie własne.

${ }^{37} \mathrm{X}^{2}(4, \mathrm{~N}=335)=37,49 ; \mathrm{p}<0,001 . \mathrm{V}$-Cramera $=0,335$.

38 D. Batorski, Korzystanie..., s. 318. 
Badanie rodzajów czynności wykonywanych przez badanych podczas korzystania z Internetu, pozwoliło odkryć dwa podstawowe typy orientacji, czy też syndromy zachowań, wyjaśniające łącznie 49,4\% zmienności wejściowego zbioru danych ${ }^{39}$. Pierwszy wymiar, nazwany informacyjno-utylitarnym, tworzyły, takie zmienne, jak: korzystanie z poczty elektronicznej (e-mail), poszukiwanie informacji za pośrednictwem wyszukiwarki (np. Google), korzystanie z internetowych encyklopedii i słowników, korzystanie z bankowości internetowej i opłacanie rachunków przez Internet, odwiedzanie obcojęzycznych stron WWW. Drugą syntetyczną zmienna, orientację na rozrywkę i komunikację, wyznaczały następujace zachowania: czytanie plotek i ciekawostek (na portalach typu Pudelek), odwiedzanie portali społecznościowych typu Nasza Klasa czy Facebook, uczestniczenie w czatach, forach lub grupach dyskusyjnych, oglądanie filmików na YouTube, korzystanie z komunikatorów typu Gadu-Gadu, słuchanie muzyki, radia lub oglądanie filmów, seriali, telewizji, szukanie pracy, wysyłanie ofert dotyczaccych zatrudnienia. Zmienne tworzace układ współrzędnych (zob. schemat 1) przedstawiono w postaci standaryzowanej, gdzie wartość „0” oznacza średnią dla próby, a wartość „1” odchylenie standardowe danej zmiennej. Następnie na tak zdefiniowaną przestrzeń nałożono punkty reprezentujące określone cechy społeczno-demograficzne (np. kategoria społeczno-zawodowa, dochód, wykształcenie, wiek, aktywność towarzyska w podziale na „nieaktywnych” i „,aktywnych w domu i poza domem”, miejsce zamieszkania, posiadanie dzieci) ${ }^{40}$. Dało to możliwość odczytania „dystansów” społecznych w obu rozpatrywanych wymiarach internetowej aktywności.

Wyróżnione wymiary okazały się niezwykle mocno związane z pozycją społeczną badanych. Wśród przedstawicieli kategorii „klasowej” A, osób najlepiej zarabiających i z wyższym wykształceniem, silna była orientacja utylitarna, zwiąana z poszukiwaniem wiedzy, czemu towarzyszyło odrzucenie rozrywkowo-ludycznego charakteru Internetu (co potwierdzałoby wcześniejsze ustalenia). Osoby już społecznie uprzywilejowane (o wyższych kapitałach) maja tendencję do pomnażania zasobów i zabezpieczania własnej pozycji społecznej, czemu towarzyszy odrzucenie wszelkich „nieproduktywnych” czy „marnotrawnych” aktywności ${ }^{41}$. Charakterystyczna była w tym kontekście wypowiedź jednej z respondentek z kategorii A: „Moderator: A właśnie, czy ma Pani może jakieś stałe strony internetowe czy blogi, które Pani śledzi? Respondent: Żadnych blogów, żadnych Facebooków, Naszych Klas - nie staram się z tego nie korzystać. Chociaż jestem zarejestrowana i swoich znajomych gdzieś tam w ten sposób też odnajdywałam po latach i dzięki temu wiem, co się u nich dzieje. A jeśli chodzi o takie swoje strony, no to mam stałe związane z moim

${ }^{39}$ Dla wyodrębnienia orientacji wykorzystano analizę głównych składowych 12 zmiennych opisujących rodzaje czynności wykonywanych podczas korzystania z Internetu: współczynnik $\mathrm{KMO}=0,861$, rotacja Varimax. Wyodrębniono dwa czynniki: 1. Czynnik wyjaśniał 38,3\% wariancji pierwotnego zbioru danych a 2 . Czynnik: $11 \%$.

${ }^{40}$ Różnice pomiędzy kategoriami społeczno-ekonomicznymi na 2 wymiarach były istotne statystycznie przy $\mathrm{p}<0,001$ lub $\mathrm{p}<0,05$ (miejsce zamieszkania, dochód).

${ }^{41}$ Por. M. Nawojczyk, Czas wolny - pochodna czy determinanta pozycji spotecznej, w: D. Mroczkowska (red.), Czas wolny. Refleksje, dylematy, perspektywy, Difin, Warszawa 2011, s. 121-136. 
zawodem, z tym co robię. To są strony związane z marketingiem, "Harvard Business Review « - z tej strony bardzo często korzystam, »Marketing w praktyce - to są czasopisma, które wychodzą raz w miesiącu i ja zarówno kupuję w formie papierowej jak i czytam na bieżąco w Internecie”. Dostrzegamy tutaj praktyczny i nastawiony na akumulację kapitału typ uczestnictwa w szeroko rozumianej kulturze, wyjaśniający zjawisko rosnących dysproporcji między różnymi grupami społecznymi (tzw. efekt św. Mateusza ${ }^{42}$.

Większe nastawienie na rozrywkę i relacje międzyludzkie znamionowało z kolei osoby z kategorii C, np. pracowników handlu i usług, wśród których aż 38,7\% wykazywało wysoką wartość omawianej zmiennej (tj. wartość powyżej jednego odchylenia standardowego od średniej), w porównaniu np. z kierownikami i menedżerami (7,7\%). Zarówno zatrudnieni w handlu i usługach, jak i pracownicy fizyczni sytuowali się poniżej przeciętnej w wymiarze utylitarno-informacyjnym (schemat 1), co oznacza, że rzadziej wykorzystywali Internet w celu pogłębiania wiedzy czy dla rozwoju osobistego. Zauważyć można także takie kategorie społeczne, które przejawiały zrównoważony typ orientacji internetowych, tj. wykorzystywały Internet zarówno do rozrywki, jak i w celach pragmatycznych. Dotyczyło to szczególnie osób młodych (18-25 lat), nieposiadających dzieci, aktywnych społecznie w domu i poza domem (zob. górna prawa ćwiartka schematu 1). Na przeciwnym biegunie wykresu sytuowały się z kolei osoby starsze (46-55 lat), nieaktywne towarzysko oraz posiadajace dzieci. Jednak szczególnie ta pierwsza kategoria wyróżniała się niezwykle słabym uczestnictwem w obu rozpatrywanych typach korzystania z sieci (nie interesował ich ani rekreacyjny, ani też utylitarno-informacyjny charakter Internetu).

Szczególnie silny związek zachodził między poziomem wykształcenia i dochodem a wymiarem informacyjno-użytkowym. Im wyższe zasoby kapitału kulturowego (współczynnik korelacji Spearmana, rho $=0,413$; p < 0,001) i ekonomicznego ( $r h o=0,410 ; \mathrm{p}<0,001$ ), tym silniejsza była orientacja na praktyczne i przynoszące wymierne korzyści użytkowanie sieci.

Spośród innych zależności na uwagę zasługuje ten między typem serialowym (dotyczącym telewizji) a orientacją na rozrywkę i komunikację. Otóż „miłośnicy seriali” telewizyjnych (wyodrębnieni w osobnej analizie) traktowali Internet przede wszystkim jako medium do rekreacji oraz utrzymywania społecznych kontaktów ${ }^{43}$. Pewne dyspozycje habitusu dostrzegalne w obszarze telewizji znajdowały odpowiednik także w innych sferach życia społecznego (tzw. przekładalność habitusu).

Choć wyróżnione grupy czy segmenty społeczne różniły się stosunkiem do sposobów spędzania czasu przed komputerem, nie koniecznie oznacza to podejmowanie zupełnie innych zachowań. Także wśród „górnych” warstw zawodowych nie brakowało miłośników portali społecznościowych, choć jak wskazują badania „Diagnozy społecznej 2011”, w łonie samych użytkowników

${ }_{42}$ Por. K. M. Słomczyński, K. Janicka, Dychotomie w strukturze klasowej: o efekcie świętego Mateusza i pogłębiajacych się nierównościach społecznych, w: J. Mucha, E. Narkiewicz-Niedbalec, M. Zielińska (red.), Co nas taczy, co nas dzieli?, OW Uniwersytetu Zielonogórskiego, Zielona Góra 2008.

${ }^{43} \operatorname{Eta}=0,328$; różnice istotne statystycznie przy p $<0,001$. 
tych portali dostrzec można znamienne podziały klasowe (np. odmienny profil użytkowników Naszej Klasy i Facebooka) ${ }^{44}$. Co więcej, sam sposób korzystania może społecznie różnicować. Oto wypowiedź jednej z przedstawicielek kategorii A, zawierająca przykład dość twórczego wykorzystania mediów społecznościowych:

M: A ma Pani, nie wiem, jakieś stałe blogi czy strony internetowe, które Pani śledzi, tak na zasadzie właśnie, jakby zamiast czytania magazynów pewnych?

R: Mhm, to są strony poświęcone HR i wizerunkowi pracodawcy, więc to są blogi, to są serwisy branżowe, to jest Facebook - zwłaszcza pod tym kątem. No i co jeszcze? Strony związane z marketingiem, kampaniami społecznymi, jakimś tam marketingiem wirusowym, blogi, to.

\section{ZAKOŃCZENIE}

Zgromadzone do tej pory dowody empiryczne na temat korzystania z Internetu dość jednoznacznie wskazują na jego „klasowy” charakter, tym samym zwiększają prawdopodobieństwo hipotezy, że osoby o ponadprzeciętnych wartościach kapitału przejawiają bardziej prorozwojowe nastawienie, tj. częściej niż „gorzej” ulokowani w strukturze dążą do pozyskiwania nowych i strategicznych zasobów. Jednocześnie pełne potwierdzenie tego przypuszczenia wymagałoby badań podłużnych (np. panelowych) obrazujaccych, jak „dzisiejsze” korzystanie z sieci przekłada się na „późniejsze” korzyści (np. zarobki, pozycja zawodowa, zdrowie, kapitał społeczny itp. ${ }^{45}$. Inny kierunek dalszych dociekań wyznacza konstatacja, że podobieństwo zachowań internetowych niekoniecznie implikuje podobieństwo praktyk społecznych, czego przykładem mogą być różne sposoby korzystania z portali społecznościowych (np. nastawienie na rozrywkę i towarzyskość vs orientacja na naukę i wymianę strategicznych informacji). Zastosowanie znajduja tu jakościowe metody badawcze (np. netnografia $)^{46}$.

Przykład Internetu dowodzi, że wbrew tezom determinizmu technologicznego, technologia ta jest silnie zakorzeniona w danym kontekście społecznym, a jej wykorzystanie - współokreślane już posiadanymi zasobami (kapitałami), w tym nabytymi dyspozycjami (habitusem klasowym). Na przekór optymistycznym oczekiwaniom sam dostęp do technologii nie niweluje społecznych nierówności. Te bowiem związane są z różnicami w zakresie umiejętności, preferowanych sposobów i celów wykorzystania, motywacji czy też możliwości praktycznego spożytkowania zasobów internetowych w życiu codziennym.

dr Michat Cebula

Uniwersytet Wroctawski

mcebula@wns.uni.wroc.pl

${ }^{44}$ D. Batorski, Korzystanie..., s. 318-319.

${ }_{45}$ Por. P. DiMaggio, B. Bonikowski, Make Money Surfing the Web? The Impact of Internet Use on the Earnings of U. S. Workers, „American Sociological Review” 73, 2008, s. 227-250.

${ }^{46}$ Por. R. V. Kozinets, Netnografia. Badania etnograficzne online, WN PWN, Warszawa 2012. 


\section{SOCIAL STRATIFICATION OF IT SKILLS. REDUCTION OR REPRODUCTION OF SOCIAL INEQUALITIES?}

\section{Sum mary}

This paper revolves around questions whether the advent of global Web has challenged social stratification. Contrary to many utopian claims it is argued that technology is embedded in existing social cleavages and relations of power, rather than contributing to redressing them. This problem, called 'digital divide' has evolved from a simple distinction between users and non-users to more refined understandings including inequalities, also among Internet users themselves. Informed by Bourdieu's theory of capital, the paper analyses the data collected on the Internet activities of Wrocław inhabitants. The findings suggest that even if the basic Internet access is controlled, the socioeconomic status (and class position) is an important predictor of how people incorporate the Web into their everyday lives. As has been shown, those from more privileged backgrounds use it in a more 'capital-enhancing' way. Two main Internet orientations have been identified: informational-utilitarian and communicational-recreational, both correlated with social position markers such as class, cultural and economic capital. This all leads to the conclusion that technology can never be detached from its place in a social and cultural context. 
Copyright of Journal of Law, Economics and Sociology is the property of Faculty of Law and Administration of Adam Mickiewicz University in Poznan and its content may not be copied or emailed to multiple sites or posted to a listserv without the copyright holder's express written permission. However, users may print, download, or email articles for individual use.

Właścicielem praw autorskich do „Ruchu Prawniczego, Ekonomicznego i Socjologicznego” jest Wydział Prawa i Administracji Uniwersytetu im. Adama Mickiewicza w Poznaniu. Zawartość czasopisma nie może być kopiowana, przesyłana do innych stron internetowych bądź zamieszczana na blogach bez pisemnej zgody wydawcy. Niemniej artykuły można drukować, kopiować lub przesyłać w formie elektronicznej na własny użytek. 